Слово “блокчейн» стало уже привычным не только пионерам криптоэкономики, но плотно вошло в лексикон политиков и юристов по всөму миру, В нашей стране по целому ряду причин, включая традиционную любовь к информационным технологиям и присущий нашим людям технооптимизм, увлечение технологиями распределенного реестра достигло ужө масштөбов хайпа (другое ставшее уже привычным в дискуссиях о цифровой экономике английское слово, прочно укоренившееся на нашей почве). Представлөниө о блокчейне как о заветном философском камне, позволяющем превращать абстрактные вычисления в свободно конвертируемую валюту, или как

о панацее, разом избавляющей от всех недостатков системы государственного управления, - это интересный феномен, заслуживающий всесторонней оценки. Ведь влияние технологий блокчейна и сопутствующей ему веры в социальные и экономические изменения уже затрагивает самые разные сферы нашей жизни - от финансов до оборота недвижимости и интеллектуальных прав.

В Ваших руках первая книга, подводящая промежуточные итоги проникновения технологий распределенного реестра в правовую сферу.

В ней мы постарались описать ключевые риски и возможности для сферы нормативного регулирования экономической жизни. Книга подготовлена командой Института права и развития ВШЭ - Сколково, исследовательского проекта сотрудничества НИУ ВШӨ и Фонда «Сколково».

Более подробно о работе Института и новых исследованиях в сфере правового регулирования криптоэкономики смотрите на нашем сайте: https://ild.hse.ru/
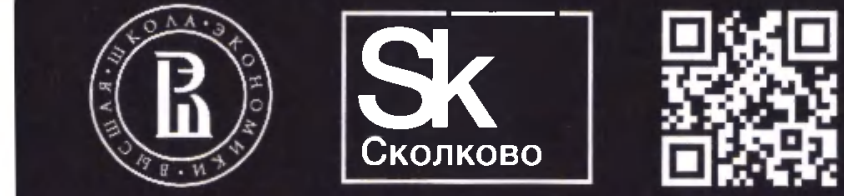


\section{Блокчейн на пике хайпа \\ правовые риски и ВОЗМОЖНОСТИ}


УДК 346

ББК 67.404 .3

Б70

Авторы:

Иванов Алексей Юрьевич (руководитель авторского коллектива) директор Института права и развития ВШЭ - Сколково;

Башкатов Максим Леонидович - ведущий научн ый сотрудник

Института права и развития ВШЭ - Сколково;

Галкова Екатерина Викторовна - ведуший научный сотрудник

Института права и развития ВШЭ - Сколково;

Тюляев Георгий Сергеевич - младший научный сотрудник

Института права и развития ВШЭ - Сколково;

Пивненко Александр Сергеевич - стажер-исследователь

Института права и развития ВШЭ-Сколково

$<$ https://ild.hse.ru/>

Блокчейн на пике хайпа: правовые риски и возможности

Б70 [Текст]/ А. Ю. Иванов (рук. авт. колл.), М. Л. Башкатов, Е. В. Галкова и др.; Нац. исслед. ун-т «Высшая школа экономики», Ин-т права и развития ВШЭ - Сколково. - М. : Изд. дом Высшей школы экономики, 2017. - 237, [3] с. - 500 экз. - ISBN 978-5-7598-1700-0 (в обл.). - ISBN 978-5-7598-1659-1 (e-book).

За период с 2009 по 2017 г. технология блокчейн стала вехой, которую нельзя игнорировать. Капитализация рынка децентрализованных технологий растет, блокчейн критикуют и им восхищаются. Вне зависимости от субъективных оценок рисковый характер транзакций в блокчейне - оборотная сторона гибкости, открытости и широких возможностей Целесообразность применения технологий должна оцениваться в каждой конкретной ситуации и отвечать современным потребностям. Разработка регулирования блокчейн-технологий отвечает запросу на формальную определенность, выступая оптимальным решением наболевших структурных вопросов. Ответы на них позволяет дать экспертиза в области права и экономики, которой посвящена настоящая книга.

Книга адресована не только практикующим юристам, сталкиваюшимся с необходимостью минимизировать риски цифровой экономики, но и всем, кто интересуется вопросами права и инноваций.

УДК 346 ББК 67.404.3

Опубликовано Издательским домом Высшей школы экономики <http://id.hse.ru>

doi: $10.17323 / 978-5-7598-1700-0$

ISBN 978-5-7598-1700-0 (в обл.) ISBN 978-5-7598-1659-1 (e-book)

(C) Национальный исследоњательский университет «Высшан ІІкола экономики", Институг прана и развития ВШЭ - Сколково. 2017 


\section{СОДЕРЖАНИЕ}

Предисловие .............................................................. 4

1. Общая характеристика технологии блокчейн и ее влияние на развитие права .................................. 19

2. Регистрация прав и учет ...................................................59

3. Регулирование торговли и блокчейн ........................... 77

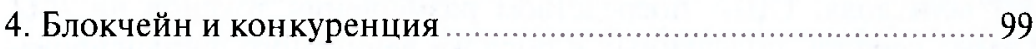

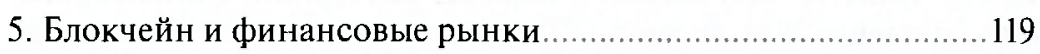

6. Блокчейн и финансовый надзор .................................. 157

7. Блокчейн в области публичного управления …............... 197

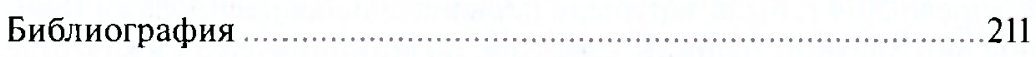

